\section{Yield and Composition of Ocimum basilicum L. and Ocimum sanctum L. Grown at Four Locations}

\author{
Valtcho D. Zheljazkovi,5 \\ Mississippi State University, North Mississippi Research and Extension \\ Center, 5421 Highway 145 South, Verona, MS 38879
}

Charles L. Cantrell ${ }^{2}$

Natural Products Utilization Research Unit, Agricultural Research Service, U.S. Department of Agriculture, P.O. Box 8048, University, MS 38677

William B. Evans ${ }^{1}$

Truck Crops Experiment Station, P.O. Box 231, Crystal Springs, MS 39059

M. Wayne Ebelhar ${ }^{3}$

Delta Research and Extension Center, P.O. Box 197, Stoneville, MS 38776

Christine Coker ${ }^{4}$

Coastal Research and Extension Center, 1815 Popps Road, Biloxi, MS 39532

Additional index words. sweet basil, holy basil, essential oil content, essential oil composition

\begin{abstract}
Sweet basil (Ocimum basilicum L.) and holy basil (Ocimum sanctum L.) are the most widely grown basil species in the world either for the fresh market or for essential oil production. Both species are considered to be promising essential oil crops in the southeastern United States; however, research on oil production and composition of these species in Mississippi and the southeastern United States is lacking. The objective of this study was to evaluate biomass productivity, oil content, and oil composition of sweet basil (Ocimum basilicum L.) cvs. German and Mesten and holy basil (Ocimum sanctum L.) cv. Local grown at four locations in Mississippi. Overall, the three basil cultivars grew well; the fresh herbage and essential oil yields at three of the locations were high and comparable to basil yields reported in the literature. Essential oil content in air-dry herbage and the essential oil yields were as follows: $0.07 \%$ to $0.50 \%$ and 0.7 to $11.0 \mathrm{~kg} \cdot \mathrm{ha}^{-1}$ in sweet basil cv. Mesten, $0.2 \%$ to $0.5 \%$ and 1.4 to $13.0 \mathrm{~kg} \cdot \mathrm{ha}^{-1}$ in sweet basil cv. German, and $0.08 \%$ to $0.40 \%$ and 0.6 to $5.3 \mathrm{~kg} \cdot \mathrm{ha}^{-1}$ in holy basil cv. Local, respectively. The main constituent of sweet basil cultivars was (-)-linalool with other constituents being (-)camphor, $\alpha$-humulene, eucalyptol, eugenol, (-)-bornyl acetate, methyl chavicol, (-)trans-caryophyllene, $\alpha$-trans-bergamotene, and cadinol. The main constituents of holy basil were methyl chavicol, eugenol, and eucalyptol with other constituents being $\alpha$ humulene, humulene-epoxide II, (-)-trans-caryophyllene, $\alpha$-trans-bergamotene, and $\gamma$ cadinene. Our results suggest sweet and holy basils have a potential as new essential oil crops for Mississippi and possibly the southeastern United States and can provide oil yields and composition typical for the respective species.
\end{abstract}

\footnotetext{
Received for publication 4 Jan. 2008. Accepted for publication 5 Mar. 2008.

This research was funded by ARS Specific Coop. Agreement 58-6402-4-026 with CRIS MIS-172050 (research grant Medicinal Herbs Research in Mississippi awarded to Dr. Zheljazkov).

Contribution of the Mississippi Agricultural and Forestry Expt. Station journal article no. J-11224. We thank Mr. Thomas Horgan, Mrs. Marie Rogers, Mr. Davis R. Clark, Mr. Mike Ely, and Mr. Peter Hudson for their help in the field and laboratory and Amber Callahan for her help with quantitative data analysis.

${ }^{1}$ Assistant Research Professor.

${ }^{2}$ Research Chemist.

${ }^{3}$ Research Professor.

${ }^{4}$ Associate Research Professor.

${ }^{5}$ To whom reprint requests should be addressed; e-mailvj40@pss.msstate.edu
}

Trevisan et al., 2006). Basil essential oil has been traditionally extracted from whole aboveground herbage (stems, leaves, and flowers) using steam distillation (Topalov, 1962; Trevisan et al., 2006). The optimal harvesting stage for essential oil production is at flowering, when the oil content and preferred composition are the highest (Topalov, 1962; Zheljazkov, 1998). Various basil species and cultivars provide essential oil with different compositions and aroma. The chemotaxonomical range of sweet basil is very wide. For example, in a study on 270 sweet basil accessions, the major constituents were found to be (-)-linalool (up to $71 \%$ ), methyl chavicol, or citral and 1,8-cineole, (-)camphor, thymol, methyl cinnamate, eugenol, methyleugenol, methyl isoeugenol, and elemicin (Kruger et al., 2002). According to Marotti et al. (1996), the European basil type has (-)-linalool and methyl chavicol as the major oil constituents. The Reunion basils, another chemotype, have methyl chavicol as a major constituent, whereas tropical chemotypes of basil have methyl cinnamate as the major constituent. Another basil chemotype grown in North Africa, Russia, Eastern Europe, and parts of Asia has eugenol as the major constituent (Marotti et al., 1996).

Crop producers are always looking for high-value specialty crops, and some producers expressed interest in basil as an essential oil crop in Mississippi. However, research on basil productivity, the essential oil content and composition in Mississippi and in the southeastern United States is lacking. The objective of this study was to evaluate productivity, oil content, and composition of sweet and holy basils grown at four locations in Mississippi.

\section{Materials and Methods}

Plant materials and growing conditions. A replicated field experiment (a randomized complete block design with four replications) was conducted in the 2006 cropping season at four locations in Mississippi: Beaumont, Crystal Springs, Stoneville, and Verona, located in the four main geographic areas of Mississippi (Fig. 1). The test material was cv. German and cv. Mesten of sweet basil (O. basilicum L.) and cv. Local of holy basil (O. sanctum L.). All seedling production was initiated in March in one greenhouse at Verona using certified seeds from the Research Institute for Roses and Medicinal Plants in Kazanluk, Bulgaria. Basil seedlings were initiated in 48-cell plastic trays filled with Metro-mix 300 growth medium (The Scotts Co., Marysville, $\mathrm{OH}$ ) sown by hand and thinned after emergence to one plant per cell. Basil seedlings grew for 6 weeks under natural light with a day temperature of 22 to $25^{\circ} \mathrm{C}$ and night temperature of $18{ }^{\circ} \mathrm{C}$. Plants were irrigated once every $24 \mathrm{~h}$ and fertilized weekly with $1.8 \mathrm{~g}$ of $20-20-20 \mathrm{~N}-\mathrm{P}_{2} \mathrm{O}_{5}-\mathrm{K}_{2} \mathrm{O}$ dissolved in $300 \mathrm{~mL}$ of water during the greenhouse seedling production period. All basil plants were transplanted into the field in 
May 2006 in previously prepared black were taken and were extracted for phytoavailable nutrients using the Lancaster soil test method (Cox, 2001) (Table 1). Land several times and the formation of raised beds using a press-pan-type bed shaper. The bed shaper machine also covered the beds with black plastic mulch and placed a drip-tape irrigation tube under the plastic. The system of black plastic mulch combined with drip irrigation was selected to provide uniform weed control, improved water relations, metered fertility, and cleaner harvested crop than a bare ground system would have. Also, the black plastic reduced cultivation adjacent to plants. The resulting beds were $15 \mathrm{~cm}$ high and $75 \mathrm{~cm}$ wide across the top. Basil seedlings were transplanted in two rows on each bed, in an offset pattern, with $30 \mathrm{~cm}$ in-row and between-row spacing. The individual plots (replication) had 40 plants and were $6 \mathrm{~m}$ long. Irrigation was done through the plastic-covered raised beds.

Before land preparation, soil samples preparation in early spring included disking

subsurface drip irrigation tape on a weekly basis; fertilizers were supplied through the drip tape weekly to supply a total of 120,80 , and $100 \mathrm{~kg} \cdot \mathrm{ha}^{-1}$ of $\mathrm{N}, \mathrm{P}_{2} \mathrm{O}_{5}$, and $\mathrm{K}_{2} \mathrm{O}$ over the growing season. There are only two common weeds in the area that can grow through the plastic-yellow nutsedge (Cyperus esculentus) and purple nutsedge (C. rotundus) - and these were removed several times by handweeding. In general, sweet basil reached beginning of flowering 2 to $3 \mathrm{~d}$ earlier than holy basil. Both species set up many flowers and have a much extended flowering stage, which allowed for a harvest at the same time. Also, although the shape of inflorescences and individual leaves are different between the species, both species have similar overall plant shape.

All basil plants were harvested by hand in full bloom ( 7 weeks after transplanting) by cutting at $10 \mathrm{~cm}$ aboveground, the fresh and air-dry weights were recorded, and the plants were dried at a temperature of $40{ }^{\circ} \mathrm{C}$ to preserve the essential oil content and composition (Topalov, 1962). Basil could provide

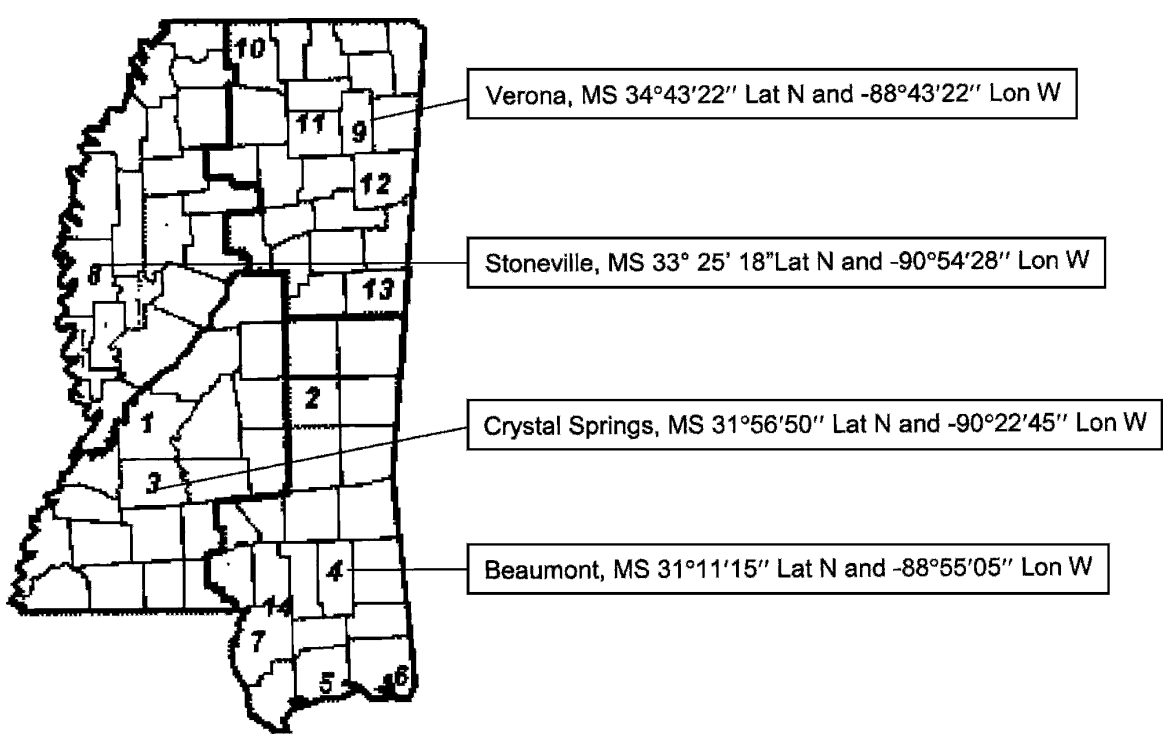

Fig. 1. Map of Mississippi with indication of the counties and the Mississippi Agriculture and Forestry Experiment Stations (MAFES) (1-14). The field experiments were conducted at the MAFES research stations in Beaumont (4), Crystal Springs (3), Stoneville (8), and Verona (9). two to three harvests; however, in that case, it must be cut relatively high so some leaves and secondary branches remain intact. Basil cutting at $10 \mathrm{~cm}$ above soil surface (which is typical for field production systems where basil is cut with machinery and distilled for essential oil) does not allow for regrowth. Hence, the data in this study reflect a single harvest. The essential oil from all air-dried basil samples was extracted using a modified Clevenger collector apparatus (Furnis et al., 1989). A sample size of $150 \mathrm{~g}$ of air-dry aboveground material (stems, leaves, and flowers from six plants from the middle of every plot) and a distillation time of 120 min were used.

Essential oil sample preparation and compositional gas chromatography-mass spectrometry analysis. The essential oil from each treatment was weighed, and the oil content was calculated as the weight $(\mathrm{g})$ of oil per weight $(\mathrm{g})$ of dried basil herbage. Essential oil samples were prepared using a micropipette by transferring $100 \mu \mathrm{L}$ of oil from each sample into a $10-\mathrm{mL}$ volumetric flask and brought to volume with $\mathrm{CHCl}_{3}$. Furthermore, a $1-\mathrm{mL}$ aliquot of each oil sample was transferred into a gas chromatograph vial for analysis. Gas chromatograph grade chemical standards and the basil oils from the field experiment were analyzed by gas chromatography-mass spectrometry (GC-MS) on a Varian CP-3800 (Palo Alto, CA) GC attached to a Varian Saturn 2000 MS/MS. The GC was fitted with a DB-5 fused silica capillary column $(30 \mathrm{~m} \times 0.25$ $\mathrm{mm}$, with film thickness of $0.25 \mu \mathrm{m}$, splitless injection) operated under the following program: injector temperature, $240{ }^{\circ} \mathrm{C}$; column temperature, 60 to $240{ }^{\circ} \mathrm{C}$ at $3{ }^{\circ} \mathrm{C} / \mathrm{min}$ then held at $240{ }^{\circ} \mathrm{C}$ for $5 \mathrm{~min}$; carrier gas, He; injection volume, $1 \mu \mathrm{L}$ (splitless); MS mass range from 40 to $650 \mathrm{~m} / \mathrm{z}$; filament delay of $3 \mathrm{~min}$; target total ion chromatogram (TIC) of 20,000; a prescan ionization time of 100 $\mu$ sec; an ion trap temperature of $150{ }^{\circ} \mathrm{C}$; manifold temperature of $60{ }^{\circ} \mathrm{C}$; and a transferline temperature of $170{ }^{\circ} \mathrm{C}$.

Quantitative analysis. Commercial standards of eugenol, methyl chavicol, and (-)trans-caryophyllene were purchased from Aldrich (St. Louis, MO), whereas (-)-linalool, (-)-camphor, $\alpha$-humulene, eucalyptol,

Table 1. Initial soil characteristics $(0$ to $15 \mathrm{~cm})$, the concentration of extractable nutrients in the soil, and the average daily minimum and maximum temperatures of the four locations in Mississippi during basil growth.

\begin{tabular}{|c|c|c|c|c|c|c|c|c|c|c|c|c|}
\hline Location & Soil type & $\mathrm{pH}$ & $\mathrm{OM}^{\mathrm{z}}$ & $\mathrm{P}$ & $\mathrm{K}$ & $\mathrm{Ca}$ & $\mathrm{Mg}$ & $\mathrm{Zn}$ & $\mathrm{S}$ & $\mathrm{Na}$ & $\begin{array}{c}\operatorname{Max} \\
\mathrm{T}^{\mathrm{x}} \\
\end{array}$ & $\begin{array}{c}\text { Min } \\
\mathrm{T}\end{array}$ \\
\hline Beaumont & $\begin{array}{l}\text { McLaurin } \\
\text { sandy loam }\end{array}$ & $5.8 \mathrm{c}$ & $0.67 \mathrm{~b}$ & $240 \mathrm{a}^{\mathrm{y}}$ & $268 \mathrm{~b}$ & $731 \mathrm{~b}$ & $99 \mathrm{c}$ & 2.0 & 109 & $136 \mathrm{~b}$ & 33.3 & 18.2 \\
\hline Stoneville & $\begin{array}{l}\text { Bosket } \\
\text { very fine } \\
\text { sandy loam }\end{array}$ & $6.7 \mathrm{a}$ & $0.95 \mathrm{a}$ & $103 \mathrm{~b}$ & $401 \mathrm{a}$ & $2933 \mathrm{a}$ & $526 \mathrm{a}$ & 4.8 & 153 & $360 \mathrm{a}$ & 31.4 & 18.7 \\
\hline
\end{tabular}

\section{${ }^{\mathrm{z}} \mathrm{OM}=$ organic matter,}

${ }^{\mathrm{y}}$ Means within columns followed by different letters are significantly different at $P<0.05$.

xThe average daily maximum and minimum temperatures were averaged from the daily maximum and minimum temperatures at the four locations for the period 1 May to 30 June 30. 
and (-)-bornyl acetate were purchased from Fluka (Buchs, Switzerland). A previously isolated and characterized compound, humulene epoxide II, was used as a standard as well (Cantrell et al., 2005). With five concentration points, an external standard least squares regression for quantification was used. Separate calibration curves were formulated for each of the nine analytes. Linearity was imposed by using response factors and regression coefficients independently. The response factors were calculated using the equation $\mathrm{RF}=\mathrm{DR} / \mathrm{C}$ where $\mathrm{DR}$ is the detector response in peak area (PA) and $\mathrm{C}$ is the analyte concentration. The range of analysis was from 1.0 $\mathrm{mg} \cdot \mathrm{mL}^{-1}$ to $0.0001 \mathrm{mg} \cdot \mathrm{mL}^{-1}$ and $\mathrm{R}^{2}$ values were 0.994 or higher for all analytes.

The resulting oil chromatograms from each sample from the field experiments were compared with the standard injections, and the target peaks were confirmed by both retention time and mass spectra. The confirmed integrated peaks were used to determine the percentage of each chemical constituent in the essential oil from each sample. The "percent in oil" for each sample was determined using the RF of the target chemical constituent and using the equation: $[(\mathrm{PA} / \mathrm{RF}) / \mathrm{C}]^{*} 100=\%(\mathrm{PA}=$ peak area of analyte from sample injection; $\mathrm{RF}=$ response factor of analyte; $\mathrm{C}=$ concentration of sample) in oil. Percent is therefore a wt/wt percentage of analyte in oil. Injection volume was $1 \mu \mathrm{L}$ for samples and standards.

There were three commercially unavailable analytes ( $\alpha$-trans-bergamotene, $\gamma$-cadinene, and cadinol) that were major constituents in some of the basil samples (Fig. 2). Identification of these components was obtained using retention times, Kovats indices, and mass spectra. Kovats indices were calculated using the equation $\mathrm{KI}(\mathrm{x})=100[(\log \mathrm{RT}(\mathrm{x})-$ $\left.\log \mathrm{P}_{\mathrm{z}}\right) /\left(\log \mathrm{RT}\left(\mathrm{P}_{\mathrm{z}+1}\right)-\log \mathrm{RT}\left(\mathrm{P}_{\mathrm{z}}\right)\right]$ where: $\mathrm{RT}\left(\mathrm{P}_{\mathrm{z}}\right) \leq \mathrm{RT}(\mathrm{x}) \leq \mathrm{RT}\left(\mathrm{P}_{\mathrm{z}+1}\right)$ and $\mathrm{P}_{4} \ldots \mathrm{P}_{25}$ are n-paraffins.

All data analyses of oil content, air-dry herbage, and essential oil yields were done using one-way analysis of variance in Quattro Pro (Corel, Ottawa, Ont., Canada).

\section{Results and Discussion}

The four locations had dissimilar soil characteristics; soil pH was lower in Beaumont and Crystal Springs and higher in Stoneville and Verona, and the soil at Beaumont was lower in organic matter relative to the other locations (Table 1). The phytoavailable nutrients (extracted with the Lancaster soil test method) had different concentrations at the four locations; the soil in Verona had relatively lower concentrations of $\mathrm{P}$ and $\mathrm{K}$ compared with the other locations. Stoneville had the highest values for nearly every soil parameter measured. Although basil is notorious for diseases, especially in warm and humid climates (Dudai et al., 2002; Holcomb and Cox, 1998), we did not detect any disease infestation on sweet or holy basils at the four experimental sites in Mississippi.
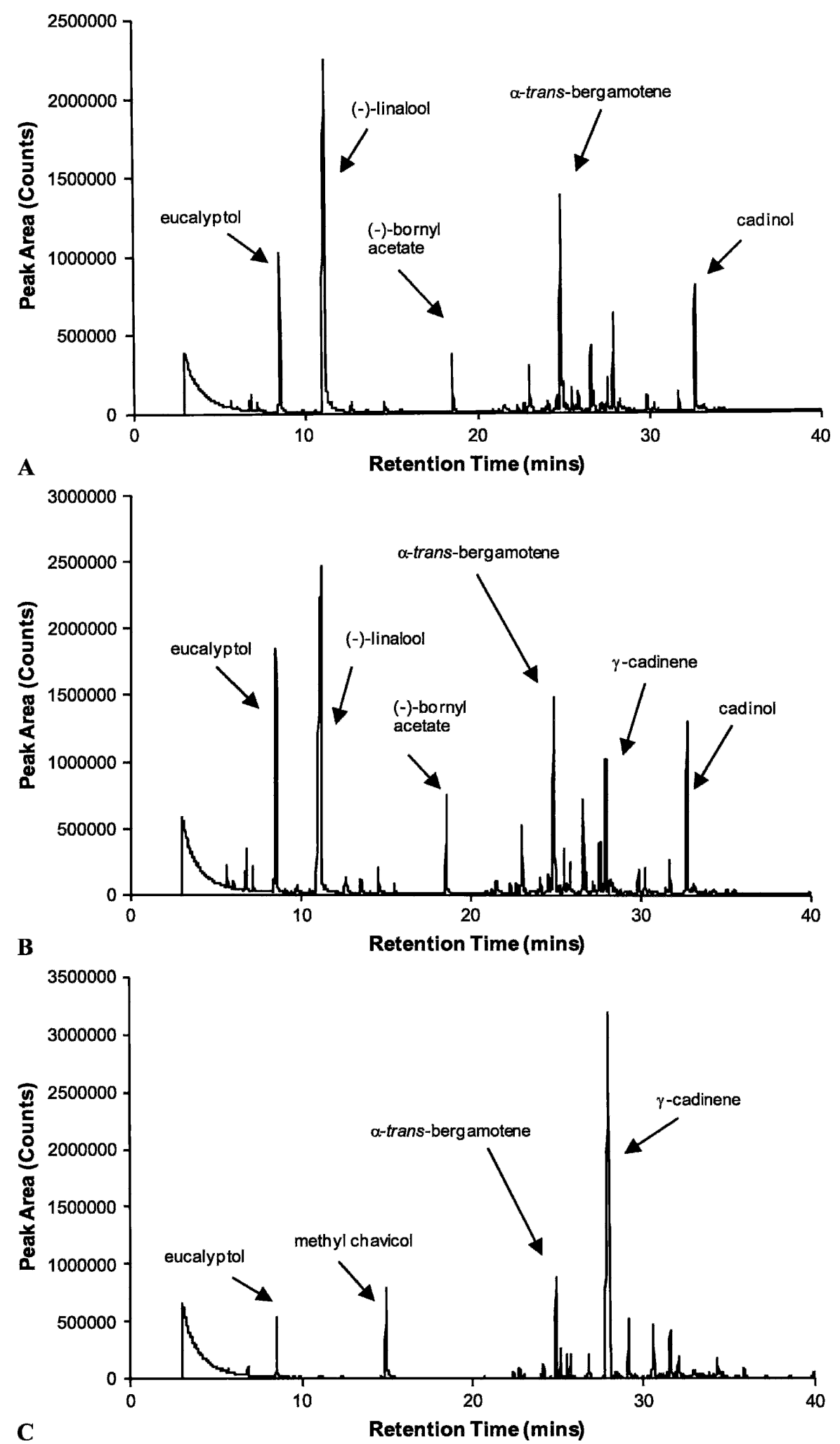

Fig. 2. Representative chromatograms of (A) sweet basil (O. basilicum) cv. Mesten, (B) sweet basil (O. basilicum) cv. German, and (C) holy basil (O. sanctum) cv. Local.

Herbage yields. The three basil cultivars yielded differently at the four locations (Table 2). Yields of cv. Mesten were the highest in Stoneville, lower in Crystal Springs, and the lowest in Verona and Beaumont. Air-dry matter yields of cv. German of sweet basil were the highest in Crystal
Springs, lower in Stoneville and Verona, and the lowest in Beaumont. Yields of holy basil cv. Local were the highest in Verona, lower in Crystal Springs and Stoneville, and the lowest in Beaumont. In Beaumont and Stoneville, cv. Mesten of sweet basil had higher yields than the other two cultivars. In 
Table 2. Effect of genotype on air-dry matter herbage yields $\left(\mathrm{DMY}^{\mathrm{z}}\right)$, essential oil content, and oil yields of basil.

\begin{tabular}{|c|c|c|c|c|}
\hline Species, measurement & Beaumont & Crystal Springs & Stoneville & Verona \\
\hline \multicolumn{5}{|l|}{ O. basilicum cv. Mesten } \\
\hline DMY, kg.ha ${ }^{-1}$ & $1025 \mathrm{cA}^{\mathrm{y}}$ & 1789 bB & $3275 \mathrm{aA}$ & $1446 \mathrm{cB}$ \\
\hline Oil content $\mathrm{c}^{\mathrm{x}}, \%$ & $0.067 \pm 0.031$ & $0.354 \pm 0.033$ & $0.344 \pm 0.057$ & $0.481 \pm 0.10$ \\
\hline Oil yield ${ }^{\mathrm{w}}, \mathrm{kg} \cdot \mathrm{ha}^{-1}$ & 0.69 & 6.33 & 11.27 & 6.95 \\
\hline \multicolumn{5}{|l|}{ O. basilicum cv. German } \\
\hline DMY, kg.ha' ${ }^{-1}$ & $594 \mathrm{cB}$ & $2357 \mathrm{aA}$ & $1569 \mathrm{bB}$ & $1549 \mathrm{bB}$ \\
\hline Oil content, $\%$ & $0.236 \pm 0.15$ & $0.565 \pm 0.053$ & $0.468 \pm 0.089$ & $0.389 \pm 0.076$ \\
\hline Oil yield, $\mathrm{kg} \cdot \mathrm{ha}^{-1}$ & 1.40 & 13.32 & 7.35 & 6.02 \\
\hline \multicolumn{5}{|l|}{ O. sanctum cv. Local } \\
\hline DMY, kg·ha ${ }^{-1}$ & $786 \mathrm{cB}$ & $1539 \mathrm{bB}$ & $1284 \mathrm{bB}$ & $2406 \mathrm{aA}$ \\
\hline Oil content, $\%$ & $0.077 \pm 0.062$ & $0.346 \pm 0.029$ & $0.074 \pm 0.010$ & $0.206 \pm 0.020$ \\
\hline Oil yield, $\mathrm{kg} \cdot \mathrm{ha}^{-1}$ & 0.61 & 5.32 & 0.95 & 4.96 \\
\hline
\end{tabular}

${ }^{\mathrm{z}} \mathrm{DMY}=$ air-dry matter yields include all aboveground material (stems, leaves, and flowers).

${ }^{\mathrm{y}}$ Means with the same letters are not significantly different at $P \leq 0.05$. Lower case letters represents significance between the same cultivar in different locations (within a row). Upper case letters represent significance between cultivars within a location (within a column).

${ }^{x}$ Oil content is a wt/wt percent of oil in air-dry herbage.

${ }^{\mathrm{w}}$ Oil yield is a function of oil content and air-dry herbage yields.

Crystal Springs, cv. German of sweet basil provided the highest yields, whereas in Verona, holy basil cv. Local had higher yields than the other two cultivars (Table 2). Overall, the lowest basil herbage yield across the three cultivars was in Beaumont, the southernmost location, most probably the result of differences in soil type and climate. Beaumont has sandier soil and higher temperatures relative to the other locations (Table 1). Yields of all three cultivars at the other three locations (Crystal Springs, Stoneville, and Verona) were relatively high and comparable to literature reports from other countries (Bowes and Zheljazkov, 2004; Topalov, 1962; Zheljazkov, 1998).

Essential oil content. Oil content of cv. Mesten was also different at the four locations, with higher oil content in Crystal Springs, Stoneville, and Verona and lower in Beaumont (Table 2). Oil content of sweet basil cv. German was also lower in Beaumont relative to the other locations, although it was the most southern location with higher temperatures, which was supposed to increase oil content as indicated by previous research (Topalov, 1962). Oil content of holy basil cv. Local was the highest in Crystal Springs, lower in Verona, and the lowest in Beaumont and Stoneville (Table 2). At Beaumont and Crystal Springs, sweet basil cv. German provided higher oil yields than the other cultivars. At Stoneville, sweet basil cv. Mesten provided higher oil yields, whereas at Verona, all three cultivars had similar oil yields (Table 2).

Oil content of sweet and holy basil in this study was similar to literature reports (Anwar et al., 2005; Bowes and Zheljazkov, 2004; Marotti et al., 1996; Topalov, 1962). For example, previous reports found basil essential oil content variation between $0.07 \%$ and 1.37\% (Anwar et al., 2005; Pino et al., 1994; Wetzeil et al., 2002). Simon et al. (1999) reported basil oil content ranging from $0.04 \%$ to $0.70 \%$ in a study of a number of basil accessions in the United States. In a large study on 270 sweet basil accession in Germany, oil content in air-dry leaves (leaves only) varied from traces to $2.65 \%$ (Kruger et al., 2002). The same authors reported a great variation in chemical composition among the 270 accessions. Except for the oil yields at Beaumont, oil yields of the cultivars in this study were within the range for sweet and holy basil reported in the literature (Bowes and Zheljazkov, 2004; Marotti et al., 1996; Topalov, 1962; Zheljazkov, 1998).

Essential oil composition. Overall, the oil composition was representative for sweet and holy basil (Table 3; Fig. 2) (Bowes and Zheljazkov, 2004; Zheljazkov et al., 2008). The major constituents of sweet basil cultivars were (-)-linalool and eucalyptol, whereas the major constituents of holy basil oil were eucalyptol, eugenol, and methyl chavicol. Sweet basil cultivars did not contain detectable amounts of humulene epoxide II or methyl chavicol, whereas holy basil cultivar did not have (-)-camphor or (-)-bornyl acetate (Table 3 ). All three cultivars contained a significant concentration of $\alpha$-trans-bergamotene (Fig. 2), which could not be properly quantified as a result of the unavailability of a commercial standard. Also, sweet basil cultivars contained cadinol, whereas cv. German and cv. Local had $\gamma$-cadinene (Fig. 2), which again could not be quantified as a result of the unavailability of commercial standards. As expected, oil composition of the three cultivars was slightly different at the four locations, confirming literature reports (Bowes and Zheljazkov, 2004; Topalov, 1962). For example, holy basil oil accumulated (-)linalool only at Stoneville, sweet basil cv. Mesten did not have (-)-camphor at Beaumont, whereas cv. German did not have eugenol at Crystal Springs or Beaumont (Table 3). Our results suggest sweet basil cvs. German and Mesten could fit into the (-)linalool chemotype or to the European basil according to the classification of Marotti et al. (1996).

In another study, Zheljazkov et al. (2008) analyzed commercially available essential oils from sweet basil produced in Bulgaria, Italy, India, the Seychelles, and the United

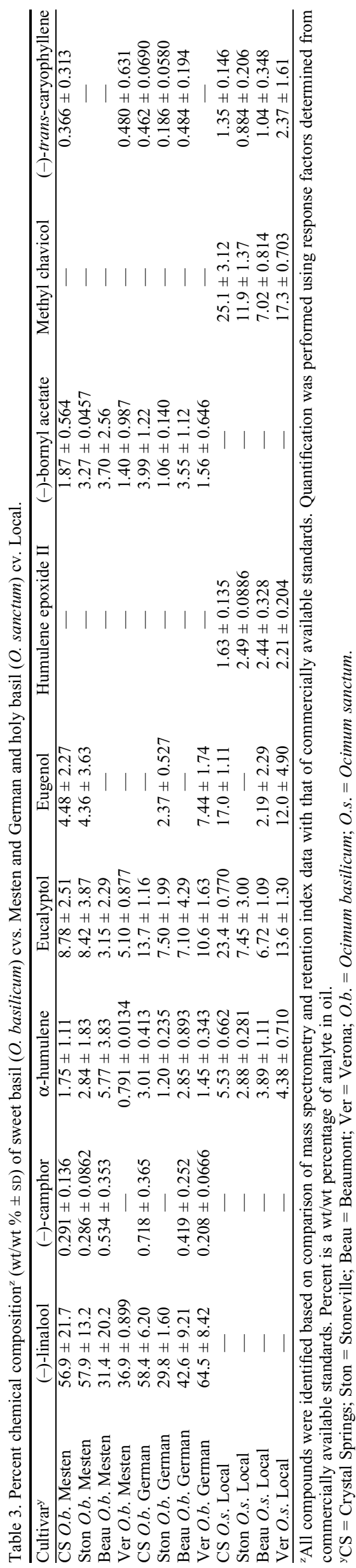

HortScience Vol. 43(3) June 2008 
States. In general, the essential oil composition of basil cultivars from this study was similar in composition to the analyzed commercial basil. Hence, basil essential oils from Mississippi and possibly the southeastern United States could be marketed the same way as basil oils already on the world market. In addition, the oil composition of the sweet and holy basil cultivars in our study was within the typical variation of the oil composition of commercial basil oils from India, France, Australia, and the Seychelles as reported earlier by Lachowicz et al. (1996).

The essential oil composition of the sweet and holy basils grown in Mississippi was comparable to another study on cv. Mesten of $O$. basilicum and cv. Local of $O$. sanctum conducted in Atlantic Canada by Bowes and Zheljazkov (2004). Interestingly, (-)-linalool concentration in both studies was similar; in the study in Atlantic Canada, the (-)-linalool concentration in cv. Mesten oil varied between $38 \%$ and $65 \%$, whereas in this study, the (-)-linalool concentration varied between $30 \%$ and $65 \%$, indicating a relatively stable range of variation for this trait. However, eugenol accumulation in cv. Mesten in Atlantic Canada was lower than eugenol in cv. Mesten in this study. Regarding cv. Local of holy basil, methyl chavicol and eucalyptol in all locations plus eugenol in Crystal Springs and Verona were the major oil constituents in our study in Mississippi, whereas the major constituents of this cultivar grown in Atlantic Canada were carene, methyl chavicol, elemene, or $\alpha$-humulene (Bowes and Zheljazkov, 2004). These compositional differences between the same cultivars grown in Mississippi and Atlantic Canada could be the result of differences in climatic conditions, soil characteristics, or production systems between the two locations and, apparently, the relatively less conservative nature of the synthesis or accumulation of these constituents at harvest. Our results suggest that even within the state of Mississippi, basil oil composition could vary considerably. This study suggests growing conditions could alter herbage yields, essential oil content, yield, and composition of sweet and holy basil. However, the exact nature of the modifying factors is not clear. There are many factors that might have influenced the chemical profile of basil (e.g., soil type, $\mathrm{pH}$, extractable nutrients, and temperature) (Table 1). This supports previous reports on the significant effect of environmental conditions on basil productivity, oil content, and composition (Javanmardi et al., 2002; Topalov, 1962).

\section{Conclusions}

The results from this study suggest that sweet basil cvs. Mesten and German and holy basil cv. Local have potential as new high- value essential oil crops for Mississippi. Except in the seasonal microclimatic conditions around Beaumont during this study, the three cultivars of sweet and holy basil could develop well under Mississippi climatic and soil characteristics and provide essential oil with typical composition for the respective species, which would facilitate marketability.

\section{Literature Cited}

Anwar, M., D.D. Patra, S. Chand, A. Kumar, A.A. Naqvi, and S.P.S. Khanuja. 2005. Effect of organic manures and inorganic fertilizer on growth, herb and oil yield, nutrient accumulation, and oil quality of French basil. Commun. Soil Sci. Plant Anal. 36:1737-1746.

Aslan, I., H. Ozbek, O. Calmasur, and F. Sahin. 2004. Toxicity of essential oil vapours to two greenhouse pests, Tetranychus urticae Koch. Bemisia Tabaci Genn. 19:167-173.

Bowers, W.S. and R. Nishida. 1980. Juvocimenes: Potent juvenile hormones mimics from sweet basil. Science 209:1030-1032.

Bowes, K. and V.D. Zheljazkov. 2004. Ocimum sanctum L. and Ocimum basilicum L. grown in Nova Scotia, Canada show potential as essential oil crops. J. Amer. Soc. Hort. Sci. 129: 789-794.

Bozin, B., N. Mimica-Dukic, N. Simin, and G. Anackov. 2006. Characterization of the volatile composition of essential oils of some Lamiaceae species and the antimicrobial and antioxidant activities of the entire oils. J. Agr. Food Chem. 54:1822-1828.

Cantrell, C.L., M. Kobaisy, C. Bryson, J.A. Klun, and S.O. Duke. 2005. Isolation and identification of mosquito-bite-deterrent terpenoids from leaves of American (Callicarpa americana) and Japanese (Callicarpa japonica) beautyberry. J. Agr. Food Chem. 53:5948-5953.

Cox, M.S. 2001. The Lancaster soil test method as an alternative to the Mehlich 3 soil test method. Soil Sci. 166:484-489.

Dudai, N., D. Chaimovitsh, R. Reuveni, U. Ravid, O. Larkov, and E. Putievsky. 2002. Breeding of sweet basil (Ocimum basilicum) resistant to fusarium wilt caused by Fusaium oxysporum f.sp. basilicum. J. Herbs Spices Med. Plants 9:45-51.

Elgayyar, M., F.A. Draughon, D.A. Golden, and J.R. Mount. 2001. Antimicrobial activity of essential oils from plants against selected pathogenic and saprophytic microorganisms. J. Food Prot. 64:1019-1024.

Furnis, B.S., A.J. Hannaford, P.W.G. Smith, and A.R. Tatchell. 1989. Vogel's textbook of practical chemistry. 5th Ed. Longman Scientific \& Technical, New York, NY, p. 171-175.

Gulcin, I., M. Elmastas, and H.Y. Aboul-Enein. 2007. Determination of antioxidant and radical scavenging activity of basil (Ocimum basilicum L. family Lamiaceae) assayed by different methodologies. Phytother. Res. 21:354-361.

Holcomb, G.E. and P.J. Cox. 1998. First report of basil leaf spot caused by Pseudomonas cichorii in Louisiana and cultivar screening results. Plant Dis. 82:1283.

Javanmardi, J., A. Khalighi, A. Kashi, H.P. Bais, and J.M. Vivanco. 2002. Chemical characterization of basil (Ocimum basilicum L.) found in 'Local' accessions and used in traditional medicines in Iran. J. Agr. Food Chem. 50:5878-5883.

Juntachote, T. and E. Berghofer. 2005. Antioxidative properties and stability of ethanolic extracts of holy basil and galangal. Food Chem. 92:193-202.

Kelm, M.A., M.G. Nair, G.M. Strasburg, and D.L. DeWitt. 2000. Antioxidant and cyclooxigenase inhibitory phenolic compounds from Ocimum sanctum Linn. Phytomed. 7:7-13.

Kristinsson, K.G., A.B. Magnusdottir, H. Petersen, and A. Hermansson. 2005. Effective treatment of experimental acute otitis media by application of volatile fluids into the ear canal. J. Infect. Dis. 191:1876-1880.

Kruger, H., S.B. Wetzel, and B. Zeiger. 2002. The chemical variability of Ocimum species. J. Herbs Spices Med. Plants 9:335-344.

Lachowicz, K.J., G.P. Jones, D.R. Briggs, F.E. Bienvenu, M.V. Palmer, S.S.T. Ting, and M. Hunter. 1996. Characteristics of essential oil from basil (Ocimum basilicum L.) grown in Australia. J. Agr. Food Chem. 44:877-881.

Marotti, M., R. Piccaglia, and E. Giovanelli. 1996. Differences in essential oil composition of basil (Ocimum basilicum L.) Italian cultivars related to morphological characteristics. J. Agr. Food Chem. 44:3926-3929.

Pino, J.A., E. Roncal, A. Rosado, and I. Goire. 1994. The essential oil of Ocimum basilicum L. from Cuba. J. Essent. Oil Res. 6:89-90.

Politeo, O., M. Jukic, and M. Milos. 2007. Chemical composition and antioxidant capacity of free volatile aglycones from basil (Ocimum basilicum $\mathrm{L}$.) compared with its essential oil. Food Chem. 101:379-385.

Simon, J.E., M.R. Morales, W.B. Phippen, R.F. Vieira, and Z. Hao. 1999. Basil: A source of aroma compounds and popular culinary and ornamental herb, p. 499-505. In: Janick, J. and J.E. Simon (eds.). Perspectives on new crops and new uses. ASHS Press, Alexandria, VA.

Suppakul, P., J. Miltz, K. Sonneveld, and S.W Bigger. 2003. Antimicrobial properties of basil and its possible application in food packaging. J. Agr. Food Chem. 51:3197-3207.

Topalov, V.D. 1962. Essential oil and medicinal plants. Hr. G. Danov Press, Plovdiv, Bulgaria.

Trevisan, M.T.S., M.G.V. Silva, B. Pfundstein, B Spiegelhalder, and R.W. Owen. 2006. Characterization of the volatile pattern and antioxidant capacity of essential oils from different species of the genus Ocimum. J. Agr. Food Chem. 54:4378-4382.

Wetzeil, S.B., H. Kruger, K. Hammer, and K. Bachmann. 2002. Investigations on morphological and molecular variability of Ocimum L. species. J. Herbs Spices Med. Plants 9:81838187

Zheljazkov, V.D. 1998. Basil, p. 317-320. In: Phehlivanor, M., G. Moskov, B. Jankov, J. Terziev, V. Zheljazkov, and H. Yantcheva (eds.). Plant production edition 1. Academic Edition of Higher Institute of Agriculture, Plovdiv, Bulgaria.

Zheljazkov, V.D., A. Callahan, and C.L. Cantrell. 2008. Yield and oil composition of thirty-eight basil (Ocimum basilicum L.) accessions grown in Mississippi. J. Agr. Food Chem. 56:241245 . 